\title{
AN ADMINISTRATIVE NIGHTMARE: ABORIGINAL CONSCRIPTION 1965-72
}

\section{Ann-Mari Jordens}

Reactions to the attempts to involve Aborigines in the National Service scheme of the 1960 s reflected the attitudes of the white community, those of Aboriginal political groups, and the development of government policy over the period in response to pressures from bodies representing both communities. On the whole the difficulties encountered by the Department of Labour and National Service in attempting to meet these demands were caused by the social effects of discriminatory government policy and practice concerning Aborigines over a long period, publicly presented as 'assimilation'. Because Aboriginal society was diverse and culturally different, and because it had long been excluded by legislation, administrative practice and custom from the rights, privileges and duties bestowed on white Australians, it did not fit neatly into the administrative framework constructed for the implementation of conscription.

Aborigines had served in the Australian Army probably since the Boer War. At least 300 Aborigines, including those of unmixed descent, served in the 1914-18 war, and three earned decorations. An estimated 1500-2000 Aborigines and 830-850 Torres Strait Islanders served as volunteers in the 1939-45 war. The Defence Act prevented the conscription of Aborigines on the grounds that, as they did not have the privileges of Australian citizenship, such as the franchise, it would be unreasonable to force them to accept the responsibilities. Although the relevant legislation allowed for Aboriginal volunteers, racially prejudiced Army administrators used Australian Military Orders and Regulations to exclude many of the them, and this practice was never challenged legally during the duration of the Second World War. When the Japanese threat to Australia became more evident the regulations relating to the employment of non-Europeans were interpreted more generously, and special groups of Aboriginal and Islanders were raised in northern Australia. There their detailed knowledge of local conditions, skills at tracking and Ann-Mari experience in tribal warfare made them experts in guerrilla fighting and mobile patrol, although they were either unpaid or very poorly paid. Aborigines integrated in the 2 nd AIF or Militia received equal pay and conditions and, despite the assumptions of Army authorities, their relations with other soldiers were generally excellent. 1

Ann-Mari Jordens is Principal Research Officer in the Official History Unit, Australian War Memorial. She is co-author of the political and social volumes of the Official History of Australia's involvement in the Vietnam Warl

1 Precise figures of Aborigines in the Army are unavailable as Army records do not identify soldiers by ethnic origin. Army administrators recorded as explaining the exclusion of Aborigines in racist terms during the war of 1939-45 were the Director of Recruiting and Mobilization and the Chief of General Staff: see Robert A. Hall, The relationship between Aborigines, Islanders and the Armed Forces in the Second World War', PhD, 1988. Also by the same author: 'Aborigines and the Army. The Second World War Experience, unpublished paper delivered to the Australian War Memorial History Conference, 8-12 February 1983; 'Aborigines, the Army and the Second World War in Northern Australia', Aboriginal History, vol.4, June 1980, pp.73-95 and Aborigines and Torres Strait Islanders in the Second World War, Strategic and Defence Studies Centre, Working Paper no. 121, Research School of Pacific Studies, Australian National University, Canberra, 198 


\section{ABORIGINAL CONSCRIPTION}

By 1964 obstacles to Aboriginal franchise were removed in all states except Queensland, and efforts were made throughout the 1960s to remove the considerable political, legislative and social barriers preventing Aboriginal participation in Australian society. In May 1963 the Department of Labour and National Service had examined Section 18 of the National Service Act, which excluded 'Aboriginal natives of Australia as defined by the regulation' from the requirement to register. An Aboriginal was defined as:

a) a full-blooded aboriginal native of Australia;

b) a person who is a half-caste aboriginal native of Australia or has an admixture of aboriginal blood greater than a half-caste; or

c) a person who has an admixture of aboriginal blood and lives as an aboriginal native or amongst aborigines. ${ }^{2}$

Nothing substantial had been achieved by November 1964 when the re-introduction of conscription was announced, except for an amendment to the wording of section 18 which enabled certain categories of Aborigines, yet to be determined, to be excluded by regulation from the obligation to register. ${ }^{3}$

The important contribution Aborigines had already made to the defence of Australia was not recognized and it was widely assumed by the Government and throughout the bureaucracy during the 1960 s that the registration of those following a traditional lifestyle would be 'neither practicable nor desirable'. The Secretary of the Department of Labour and National Service, Sir Henry Bland, believed that Aborigines on the whole would 'have considerable difficulty in adjusting themselves to the rigorous training and service requirements of the Army,' that they would not meet its medical, educational and other standards, and that ' the majority of aborigines who registered would probably be rejected following medical examination. ${ }^{4}$ The practical problems in administering the conscription of Aborigines were, however, the principal deterrent for the Department of Labour and National Service.

In early 1965 the matter came into the political arena. Protests were received from representatives of such diverse groups as the Australian Labor Party, the Aboriginal Advancement Council of Western Australia, the Australian Capital Territory Advisory Council, the Federal Council for the Advancement of Aborigines and Torres Strait Islanders, the Returned Services' League and the Country Womens' Association of Western Australia; and it was raised in Parliament by NSW Country Party member A. A. Armstrong. 5

2 Secretary, Department of Territories to the Secretary of the Department of Labour and National Service, 28 January 1964. Definition from agenda of Aboriginal Welfare Conference, 22 July 1965.

Department of Labour and National Service (hereafter L\&NS) file no. SC 67/96.

Secretary, Department of Territories to Secretary, Department of L\&NS, 26 November 1964 and Secretary of N\&NSto P.E. Felton, Aboriginal Welfare Board Victoria, 22 October 1965, L\&NS file no.SC67/96.

4 H.A. Bland to Regional Directors, 16 August 1967, pp.1-3, ibid. His successor P.H.Cook expressed similar views in a letter to the Office of Aboriginal Affairs, 3 March 1972 ,ibid.

5 Protest by Senator J. Fitzgerald, (ALP NSW) Canberra Times, 29 January 1965. Letter to Prime Minister from Aboriginal Advancement Council of Western Australia, 2 March 1965, L\&NS file no. 65/985. Protest by ACT Advisory Council, forwarded by J. O'Regan, Officer in Charge, ACT sub-office, L\&NS to the Secretary, L\&NS, 15 March 1965, L\&NS file no. SC67/96. Letter to the Minister for the Army from Stan Davey, 
Although all these bodies advocated the conscription of Aborigines they did so from very different premises. Labor and Aboriginal-controlled bodies believed that the exclusion of Aborigines implied their inferiority to white Australians as citizens. Groups such as the Returned Services' League, who espoused an assimilationist policy, believed that Aborigines should share in all the responsibilities derived from their enjoyment of the privileges of Australian citizenship.

The conference of Commonwealth and State Ministers responsible for Aboriginal Welfare, held in Adelaide on 22 July 1965, decided that Aborigines should not be excluded from registration and that those unsuitable for National Service should be excluded by administrative arrangements in collaboration with Aboriginal welfare authorities. ${ }^{6}$

This was a solution the Department of Labour and National Service firmly opposed until the scheme was abolished by the Whitlam government in 1972. Despite all the criticism and unfavourable publicity the Department attracted in trying to ensure that the existing legislation was enforced, it refused to resort to regulations or administrative action to solve the immense problems caused by inadequacies in that legislation. The Secretary of the Department insisted that if changes were to be made regarding the conscription of Aborigines they should be firmly based on an amendment of the National Service Act. This determination to base all changes on legislative amendments set the Department of Labour and National Service at loggerheads with the Department of Territories ( renamed the Department of the Interior from 29 February 1968), which throughout the period professed a strongly assimilationist policy and saw itself as the pre-eminent department in Aboriginal matters. Labour and National Service had difficulty in getting its views across on Aboriginal conscription. It was not informed of the Adelaide conference and was represented only by an observer from the South Australian Regional Office, contacted by telephone a short time before it began. ${ }^{7}$ Only state ministers attended the conference and in Parliament Gordon Bryant (ALP VIC.) criticized the Government for not taking it seriously enough to send a Commonwealth minister. ${ }^{8}$

secretary, Federal Council of the Advancement of Aborigines and Torres Strait Islanders, 2 November 1965 , loc.cit . Record of the meeting of the National Executive of the Returned Services' League of 3 August 1965, forwarded to Minister for L\&NS, 9 March 1966, L\&NS file no. 65/4360. Representation to the Minister for Defence from the Country Womens Association of Western Australia, 9 March 1966, Department of Defence file no. $182 / 1 / 30$. Protest by A. Armstrong, Commonwealth Parliamentary Debates House of Representatives (hereafter CPD HR), vol.45, p.260.

6 Conference statement 22 July 1965, p.3, L\&NS file no.SC 67/96. According to the report on this by the Minister for Territories, C.E. Barnes, these meetings were held every two years. They later became annual, CPD HR vol.49, p.3950.

7 W.F. Sharpe, Adelaide Regional Director to H.A. Bland, Secretary, L\&NS, 30 November 1965, Dr P.H. Cook, First Assistant Secretary, L\&NS, to Bland, 15 December 1965. Bland to Regional Directors, 6 December 1965, L\&NS file no.SC67/96.

8 The Minister for Territories, C. E Barnes, explained to Parliament in his Ministerial statement on Aboriginal Welfare on 10 December 1965 that the 'business of Government' had prevented him or any Commonwealth Minister from attending the conference. Bames was represented by the Administrator of the Northern Territory and the Director-General of Health represented the Minister for Health , R.W. Swartz; CPD Vol H of R 49, p.3950. An account of the attitudes prevalent in the Department of Territories on the question of Aborigines is to be found in Chapter 1 of H.C. Coombs, Kulinma. Listening to Aboriginal Australians:1-25. Unfortunately my account of the interdepartmental conflict has been reconstructed from Department of Labour and National Service files only, as at the time of writing this article the corresponding Department of Territories file (no.64/107) cannot be located. 


\section{ABORIGINAL CONSCRIPTION}

A principal architect of the Government's policy of assimilation, Professor A.P. Elkin, attended the conference. Elkin, who had occupied the Chair of Anthropology at Sydney from 1932 to 1955 , had a dominating influence on both government policy and popular perceptions of Aborigines over this period. 9 He was still a member of the NSW Aborigines Welfare Board and his advice was, as a senior officer of the Department of Labour and National Service noted, 'of quite high political importance in this matter'. Elkin considered that 'many part-Aboriginal youths should have been called up for National Service training and that the authorities have in the past been too soft in this matter. ${ }^{10}$

Although the conference softened the wording of the Government's definition of assimilation, Labor members Kim Beazley and Gordon Bryant complained that, while words had been changed, no action had resulted. They believed that while the discriminatory clauses such as those in the National Service Act remained unaltered, nothing practical had been achieved. 11

In December 1965 Bland instructed the regional directors of the Department of Labour and National Service to provide him with information which would enable the Department to determine which categories of Aborigines might be required to register. ${ }^{12}$ Although in all states the numbers of twenty-year-old Aborigines were small, the problems of fitting them into the system devised for National Service registration were insuperable. Each state had its own definition of 'Aborigine'. ${ }^{3}$ Even if an agreed definition had existed it was impossible to ascertain their numbers as Aborigines were not included in any census until 1971. State records were not always of much help, particularly with those of mixed race. The numbers of part-Aborigines (excluding those living in tribes) had not been recorded in the Northern Territory since 1953.14 Aboriginal attitudes towards marriage made the determination of 'admixture of aboriginal blood', made necessary by the Act's definition of an Aborigine, legally impossible. There were no statistics on Aboriginal marriages available. Traditional Aborigines placed no importance on legal marriages and were far less concerned about paternity than white society was. 15 In New South Wales the regional director of the Department of Labour and National Service, possibly influenced by the NSW Aborigines Welfare Board's view, believed that most Aborigines were 'less than half-caste' and that 'Aborigines cannot be sufficiently identified from the rest of the State population'.16 If 'admixture of blood' was the sole criterion he was correct, but those identifying themselves as Aborigines could have been easily ascertained. Adherence to the old criterion created insuperable problems for the Department of Labour and National Service. As one officer

9 H. Goodall, 'An Intelligent Parasite: A.P. Elkin and white perceptions of the history of the Aboriginal people in NSW'. Paper presented to the History ' 82 Conference.

10 R.A. Smee, NSW Regional Director, to Cook, 16 December 1965, Elkin's statement in agenda item 17 p.31 of conference working paper attached to letter from Secretary, Dept. of L\&NS, 23 July 1965, L\&NS file no. SC67/96,.

11 Conference 22 July 1965, agenda item 17, p.30 ibid. CPD vol. H of R. 49, 10 December 1965, p.3951 and pp.3954-5.

126 December 1965, L\&NS file no. SC67/96

13 A summary of the definitions in the various state legislations is to be found in L\&NS file no. $73 / 4914$ TA 1975 RP.

14 F.H. Moy, Department of Territories, to Bland, 10 May 1966. L\&NS file no SC67/96.

15 C.D. Rowley, Outcasts in white Australia: Aboriginal policy and practice, vol. 2:34950.

16 R.A. Smee to Cook, 16 December 1965, L\&NS file no. S C 67/96. 
observed gloomily, there were approximately 1,000 twenty year-old Aborigines throughout Australia, 'and if we have 1,000, we will have about 1,000 problem cases'.17

It was almost impossible to apply consistently the method of selection by birthday ballots to Aborigines, because varying administrative practices in the states often made it impossible to determine or verify date of birth. The registration of Aboriginal births had not been required in the Northern Territory until 1949; in South Australia it was required but the requirement was not enforced; and in Western Australia records of Aboriginal births were neither complete nor accurate being obtained mostly from hearsay information from various sources such as pastoralists, owners of stations, etc. ${ }^{18}$

The Department also noted that normal administrative practices would be difficult to apply to Aborigines who were registered. Exemptions to men married within a specified period would be complicated, as many Aboriginal marriages were regarded by authorities as de facto. ${ }^{19}$ Although there were only an estimated 200 nomadic Aborigines, many more were itinerant or seasonal workers. To prosecute them for failure to register, to notify changes of address or to attend medical examinations would be unreasonable, Bland believed, but not to do so would mean discrimination in their favour. English was not the first language of large numbers of Aborigines, and many educated in mission schools did not speak it at all, but literacy in English was a pre-requisite to registration. ${ }^{20}$ Bland continued to oppose the suggestion of the Department of Territories that these problems could be overcome by administrative discretion. Once registration was required, he argued, normal arrangements must operate. He therefore recommended that the matter be considered by Cabinet and that nothing further be done for the rest of 1966.21

On 10 January 1967 the problem was considered by a meeting of Commonwealth and State Aboriginal welfare authorities. Apparently influenced by Professor Elkin and others, ${ }^{22}$ the meeting favoured compulsory registration and selection by administrative action. Once again the Department of Labour and National Service was excluded from these discussions and even found it impossible to discover what was said at the meeting. The Department of Territories decided not to include the matter on the agenda of the Conference of Commonwealth and State Ministers responsible for Aboriginal welfare in Perth, although the Department of Labour and National Service had wished it to be raised, and had prepared a paper for it. ${ }^{23}$

Political pressure for the conscription of Aborigines was resumed when the Western Australian Branch of the Liberal party at its conference in July 1967 passed a resolution urging the Government to include more Aborigines in the call-up. The Department of Labour and National Service believed this to be nullified by the Natives (Citizenship

17 A. Sutcliffe to Cook, 2 March 1966, ibid.

18 W.K. Allen, Victorian Regional Director, to Cook, 23 December 1965 and F.H. Moy, Department of Territories, to Bland, 10 May 1966, ibid.; W.F. Sharpe, Adelaide Regional Director to Cook, 22 December 1965, ibid.; G.E. McGregor, Assistant Registrar, Perth to the Registrar, Perth, 14 February 1966, ibid.

19 S.K. Allen, Victorian Regional Director, to Cook, 22 December 1965, lbid.

20 Bland to Secretary Department of Territories, 11 March 1966 and Bland to Regional Directors, 16 August 1967, ibid.

21 Secretary, Department of Territories, to Bland, 10 May 1966 and Bland's reply, 27 September 1966, ibid.

22 R.A. Smee, NSW Regional Director, to K.C. McKenzie, Assistant Secretary, L\&NS, 26 September 1967, ibid.

23 R.S. Swift, Deputy Secretary, Department of Territories, to Bland, 11 August 1967. (Paper was dated 12 July 1967). Bland to Swift, 18 August 1967, ibid. 


\section{ABORIGINAL CONSCRIPTION}

Rights) Act of Western Australia, which prevented Aborigines from applying for citizenship until they were twenty-one - beyond the age of registration. ${ }^{24}$ On 16 August 1967 Bland again asked the regional directors to discuss the principal problems with state authorities on Aboriginal affairs. 25

At this time there was some hope that the newly created Council for Aboriginal Affairs might gain enough power to influence government policy and administration throughout the various Commonwealth departments dealing with Aborigines. The Prime Minister, Harold Holt, saw the $91 \%$ 'yes' vote in the May 1967 referendum to amend the Constitution in respect to Aborigines as a direction to the Government to act immediately to improve the status of Aborigines. On 2 November 1967 he announced the establishment of the Council for Aboriginal Affairs, a small advisory body attached to an Office of Aboriginal Affairs in Prime Minister's Department, comprising Dr H.C. Coombs, former Governor of the Commonwealth and Reserve Banks, Professor W.E.H. Stanner, Professor of Anthropology and Sociology at the Australian National University, and Barrie Dexter, then Australian Ambassador to Laos. Unfortunately, before the Council began to function Holt had died, and no subsequent Prime Minister during the existence of the Council was sufficiently interested in it to define its role or provide it with a charter. ${ }^{26} \mathrm{~W}$.C. Wentworth was made Minister in Charge of Aboriginal Affairs from 28 February 1968.

On 15 May 1968, Wentworth incorporated in a submission to Cabinet a more rational definition of 'Aboriginal' than that based on classification by 'blood'. An Aboriginal, for the purpose of the specific benefits proposed in the submission, was defined as 'a person of whole or partial Aboriginal descent who claims to be an Aboriginal and is accepted as such by the community with which he is associated ${ }^{27}$ Although this definition was clear, its status was not. Cabinet made no comment on it in its decision of $22 \mathrm{May}$, but ordered a second, more detailed submission, based on the findings of an Interdepartmental Committee. 28 The Committee's comment on this definition reflected the attitude of the Department of the Interior rather than that of the Office of Aboriginal Affairs, as it remarked that in identifying Aborigines to receive special benefits, regard might also be had to a criterion of need determined by the facts of individual cases. The Committee was conscious of the possibility of enticing Aboriginals already settled in the general community unnecessarily to seek the special benefits. ${ }^{29}$ When Cabinet considered the Committee's

24 Note to McKenzie 29 June 1967, ibid ; Natives (Citizenship Rights) Act Westem Australia, no. 23 of 1944 , sections 4-6 this was amended by no. 82 of 1964 , section 2 , to extend citizenship to the children of Aborigines granted citizenship, once those children had reached the age of twenty-one. Australian, 4 and 5 July 1967, West Australian, 5 July 1967.

25 Bland to Regional Directors, 16 August 1967 and memorandum 'Aborigines and National Service', 10 May 1966, L\&NS file no. SC67/96.

26 A detailed account of the administrative history of the Council for Aboriginal Affairs is found in Coombs, op. cit, pp.1-25.

27 Cabinet submission 92, paragraph 16, 15 May 1968, Cabinet Office file no. CO 80, part 1 .

28 Cabinet decision no 252 on submission 92, 22 May 1968, ibid.

29 Report of Interdepartmental Commitee on Submmission 92, 31 May 1968, ibid. Evidence that this represented Interior's perspective is to be found in a similar statement in Cabinet submission 269 of the Department of the Interior, paragraph 7 of 19 July 1971 which complained that some of the Council for Aboriginal Affairs' projects 'have the effect of encouraging part-Aborigines otherwise being peacefully assimilated into the general community to identify themselves with Aborigines as a group in order to get benefits they otherwise would not get.' ibid, part 2 . 
report on 2 June 1968, along with Wentworth's original submission, it affirmed its commitment to the principle of assimilation, and emphasised its desire to 'avoid proposals which, by identifying Aboriginals as such and setting them permanently apart from other Australians, are likely to have the effect of acknowledging and establishing a policy of continuing separate development leading to an eventual racial problem.' 'Full-bloods' faced different problems from 'other Aboriginal people', it declared, and its approach to solving them should therefore be pragmatic. Nevertheless Cabinet recognised the overall responsibility of the Minister in charge of Aboriginal Affairs for policy in relation to Aborigines on an Australia-wide basis. 30

Despite these inconsistencies the Office and Council for Aboriginal Affairs were successful in having the new definition accepted by most of the government departments dealing with Aborigines. By 1972 it had been accepted by all the departments represented at the Commonwealth-State meeting in Darwin, except for Interior, which would only regard 'full-blood' Aborigines as Aborigines. Alison Stephen, the Department of Labour and National Service's representative observed that it was, as a result, 'under constant criticism from other Commonwealth and State Departments'. The Employment Branch of Department of Labour and National Service accepted the new definition, but the National Service officers adhered strictly to section 18 of the National Service Act which referred to the old definition by 'blood'. The refusal of the Government to amend the National Service Act, and the determination of the Department of Labour and National Service not to deviate from the legislative provisions of the Act, meant that for the entire existence of the scheme the National Service area of the Department was hamstrung by the old, outdated and unworkable definition. 31

Nevertheless, pressure on the Department of Labour and National Service to solve its Aboriginal problem continued. In the early 1970 s it was still being urged to remove its 'discriminatory exemption' of Aborigines both by Aboriginal groups and by sections of the Country Party and the Returned Services League. ${ }^{32}$ The Attorney-General's Department, which was preparing a paper on 'existing provisions in State and Commonwealth legislation which appear to be discriminatory; also raised the issue in the light of the International Convention on the Elimination of all forms of Racial Discrimination. ${ }^{33}$

The Government never reached a formula whereby it could determine by regulation categories of Aborigines which it could conscript. The campaign to purge legislation of references to Aborigines prevented it from specifying the exclusion of tribal or nomadic Aborigines and those with unregistered or designated birthdates. In his policy speech of October 1969 the Prime Minister declared that: 'In recent years, most discriminatory legislation against Aborigines has been abolished. We intend to see that this process is completed in the life of the next Parliament upon both State and Federal levels'. Nevertheless the Government was extremely reluctant to tackle the conscription of Aborigines as it wished to avoid opening up any general discussion of the Act by

30 Cabinet decision no. 314 on submission 92, 104, 2 July 1968, ibid, part 1.

31 Alison Stephen to M. Kangan, minute, 'Departmental Definition of "Aboriginal" ', 31 August 1972, L\&NS file no SC 67/96.

32 B.G. Dexter, Director of the Office of Aboriginal Affairs, to Secretary L\&NS, 19 December 1969; Letter, F.J. Martin, Secretary, Moore Divisional Council, Country Party of Western Australia, to Secretary of the Parliamentary Country Party, 3 November 1971, ibid. ; Age, 17 March 1972.

33 B.G. Dexter to Cook, 3 January 1970 and 4 November 1970, L\&NS file no. SC 67/96. 


\section{ABORIGINAL CONSCRIPTION}

introducing new amendments. ${ }^{34}$ The Minister for Labour and National Service, B.M. Snedden, considered the issue in early 1970 but decided to do nothing because of the growing popular hostility to the Vietnam War. As the Secretary of the Department of Labour and National Service, P.H. Cook, explained to the Director of Aboriginal Affairs, 'with the ... identification of National Service with Vietnam it would doubtless be said that the Government had now reached the stage where it was calling up Aborigines to fight in Vietnam ... (T)here was, indeed, the real risk that while Australian troops remained in Vietnam successful attempts would be made to join and exploit what have been separate protest causes, namely Vietnam and Aboriginal rights. ${ }^{35}$ Opposition was anticipated 'from the Civil Rights people to the spelling out of any definition'.36 The Department of Labour and National Service, however, continued to insist on clear legislative guidelines, resisting all proposals that classes of Aborigines be excluded by administrative action. ${ }^{37}$ It refused to follow the practice, adopted by the electoral authorities, of requiring Aborigines to register as voters, but in practice making 'no strenuous efforts' to see that they did. ${ }^{38}$ Officers of the Department believed that 'If all Aborigines were required to register, we would then be obliged to take the same steps to see that they do so as in the case of any other person required to register. ${ }^{39}$

The problem became even more complicated as the Act's definition of Aborigines by proportion of 'blood' came under the test of individual cases. In March 1967 the Department was confronted with the case of a 'full blood' Aborigine who had 'lived substantially as a European', who had registered but had failed to appear for his medical. The Commonwealth Police were sent to investigate whether he was obliged to register or had registered by mistake - that is to determine whether or not he was a 'full blood' Aborigine. 40 Other people 'not hitherto perceived as Aborigines' were listed as defaulters, and in these cases the State agencies for Aboriginal Affairs were consulted. Some officers, particularly in the South Australian Department of Aboriginal Affairs, were reluctant to cooperate, arguing that it was not 'the function of that Department to arbitrate on questions of eligibility. 41

The new definition which allowed Aborigines and the Aboriginal community to identify who was, and who was not, an Aborigine, was also not without its pitfalls, as the case of Stanley Ward in Western Australia revealed in 1971-2. Charged with failing to register he argued that he did not have to as he was an Aborigine, not on the grounds of blood ( he was classed as a 'quarter-caste' and thus by Western Australian law was not an

34 Secretary L\&NS to B.G.Dexter, Director of the Office of Aboriginal Affairs, 19 February 1970 and Dexter to Cook, 29 February 1972, ibid. Prime Minister's policy speech of 8 October 1969, paragraph 6, page 2, Cabinet file no. CO 80, part 2.

Cook to Dexter, 3 February 1972, L\&NS file no. SC 67/96.

36 W.K. Allen to McKenzie, 4 September 1967, McKenzie to Sharpe, 12 October 1967, draft letter Cook to Minister, 21 November 1967, B.K. Phelan to McKenzie, 27 March 1968, ibid .

37 Bland to Director General, Department of Social Services, 11 September 1967 and B.K. Phelan to McKenzie 27 March 1968, ibid.

38 J. Tennant to Phelan, ND (folio 101) February 1968, ibid.

39 B.H. Phelan to McKenzie, 27 March 1968, ibid.

4030 March 1967, L\&NS file no. 67/1322,

4124 March 1969, W.F. Sharpe, Regional Director, South Australia, to K.C. McKenzie, 16 October 1967, and Sharpe to Secretary, 9 April 1969, L\&NS file no.SC67/96. 
Aborigine), ${ }^{42}$ but on the grounds that in the terms of the Act he was 'a person who has an admixture of aboriginal blood and lives as an aboriginal native or amongst aborigines.'

He was convicted because the magistrate interpreted this to mean that such categories of Aborigines must be following a traditional lifestyle in an Aboriginal camp or reserve. He refused to recognize that urban Aborigines had their own distinctive lifestyles and could be also regarded as living as Aborigines in an Aboriginal community. When Ward was of the age to register he was living in Derby and none of the Aboriginal youths with whom he associated registered. He regarded himself as an Aborigine on the grounds that he lived with Aborigines most of the time and engaged in distinctively Aboriginal social activities, such as taking part in demonstrations on behalf of Aboriginal rights outside Parliament House and attending Aboriginal balls and football carnivals. His sister had been granted a Commonwealth Aboriginal Study Grant and was an executive of the Aboriginal Advancement Council. Therefore she, with the same parents, was regarded both by the Commonwealth Government and by the Aboriginal community as an Aboriginal. The Prosecutor, a senior legal officer in the Deputy Crown Solicitor's Office, asserted during the trial that: 'The only way you can get out of it is to prove you were living as an aboriginal. Were you wild in the desert?' In his submission he concluded that 'The defendant has told us he lived with his aunt, who is half caste, and must give evidence to show he has lived with lesser species.' The magistrate, F.E.A. Bateman S.M., in finding Ward guilty, concluded:

I agree the defendant must show he is an aboriginal native or living amongst aborigines. I imagine this means in a camp or something similar. The defendant lives in what is apparently a normal address, he is well dressed. There has been no suggestion he lives in a camp, and he apparently lived in a house in Derby. 43

The newspapers reported that Ward felt insulted by the magistrate's remarks. 'He reckons Aborigines are not supposed to be well dressed and expects them to run around with spears. I am certainly classed as an Aboriginal when I try to find a house. I am having a lot of trouble and am discriminated against because I am Aboriginal', he complained. ${ }^{44}$ The magistrate explained that although the section of the relevant Act was not clear he took it to apply 'mainly to the uneducated bush Aboriginal'. He could not understand Ward's indignation.

I was giving him a certain amount of praise . . . I think he has taken my remarks the wrong way. He seems to be conforming to the generally accepted standards of the white community. I know there are a lot of dregs in the white race too. And there are plenty of other Aborigines like Ward who have uplifted themselves from the conditions in which they are forced to live. My remarks were a compliment to him. They were not meant to insult him or Aborigines generally. 45

42 Under section 2 (ii) of the Native Welfare Act 1905-1954 'a quadroon over 21 years of age' was not regarded as a 'Native' unless 'that person is by order of a magistrate ordered to be classed as a native under this Act, or requests to be classed as a native under this Act.'

43 Letter, Deputy Crown Solicitor, Western Australia, to Registrar, DL\&NS, Perth, 21 June 1972, and Minute, Regional Director, Perth, to Secretary, DL\&NS, with appended notes of hearing, 21 June 1972, DL\&NS file no.73/4914, TA 1975 RD.

Australian, 22 June 1972. 


\section{ABORIGINAL CONSCRIPTION}

The Australian saw 'the administrative, legal and social swamp that has developed around Aboriginals and national service' as a threat to the system as a whole. Ward would have done better 'to have smeared ochre over his neat, voguish moustache and to have left his clean, city suit at home,' it remarked sourly. ${ }^{46}$ The Truth was even more scathing. 'Presumably if Stan had painted his face and done a rain dance in the court he would have been all right. But he didn't. He behaved like a man proud of his race. For his pains he was stripped of his dignity - and $\$ 40.47$

The judgement caused the the Office of Aboriginal Affairs to complain to the Department of Labour and National Service that 'It is not a little embarrassing to have the courts ruling that persons are not Aborigines for the purposes of the Act who are for all other Commonwealth purposes regarded as Aborigines. 48

Ward appealed against this decision. His case was scheduled to appear before the High Court in December 1972 but following the election of a Labor government on 2 December, conscription was abolished. On the advice of the Department of Labour and National Service Ward dropped his appeal. ${ }^{49}$

The Vietnam decade saw significant changes in the legal status of Aborigines in Australia, and in many white Australians' perception of their place in society. The issue of the conscription of Aborigines became a focus of these changed expectations, but the Department of Labour and National Service was hamstrung by the social results of earlier laws and administrative practices, and by an unrealistic definition of Aborigines to which it was committed by legislation. All attempts to pressure the Government to review the legislation were unsuccessful. As late 16 August 1972 Senator J.L. Cavanagh (ALP SA), urged the Minister for Labour and National Service to review the definition of an Aborigine in the National Service Act to ensure its conformity with such definitions in various State Acts. ${ }^{50}$ This was rejected. The Department bore the brunt of public criticism because it insisted on strictly adhering to existing legislation. The Department of Territories (later Interior) attempted to exclude the Department of Labour and National Service from the decision-making process on Aboriginal conscription, and its belief that an administrative solution was possible influenced Government thinking. The refusal by the Department of Labour and National Service to consider administrative solutions, however, was not only correct, it was also prudent. Throughout the decade the Department's decisions were constantly surveyed by a vigilant anti-conscription movement and tested in court by numerous litigants. No other government department had its decisions subjected to such rigorous scrutiny. The Goverment refused to amend the legislation, probably at first because it thought the problem was a minor one (or because it was influenced by those believing an administrative solution was possible), and later because for political reasons it wanted to avoid opening up the whole issue of conscription. The attempt to conscript Aborigines was an administrative nightmare which was only ended for the Department of Labour and

46

47

B.G. Dexter to P. Cook, 7 September 1972, L\&NS file no.73/4914 TA 1975 RP.

49 File note by K.C. McKenzie, 14 December 1972 and minute, M.D. Robertson, Regional Director, Perth to the Secretary, DL\&NS, 20 December 1972, DL\&NS file no. 73/4914 TA 1975 RD.

50 This request was made with reference to the case of Mervyn Eades who was fined in the Perth court of Petty sessions on 13 December 1971 because the magistrate found him to be a non-Aboriginal in terms of the National Service Act, whereas in terms of Western Australian law he was considered to be an Aborigine. He was subsequently found not to meet the standards required by the Army and was not called up, CPD S vol. 53:125-6. 
National Service by the election of a Labor government, which immediately abolished conscription.

\section{BIBLIOGRAPHY}

Coombs, H. C., Kulinma. Listening to Aboriginal Australians, Canberra, 1978.

Department Of Labour and National Service, Records (Commonwealth Archives,Brighton Victoria).

Department of Prime Minister and Cabinet, Cabinet Minutes.

Goodall, H., 'An intelligent parasite: A. P. Elkin and white perceptions of the history of the Aboriginal people in NSW', Paper presented to the History ' 82 Conference.

Hall, R. A., 'Aborigines, the army and the Second World War in Northem Australia', Aboriginal History, 4, 1980:73-95

'Aborigines and the army. The Second World War experience'. Unpublished paper delivered to the Australian War Memorial History Conference, 8-12 February 1983

'Aborigines and Torres Strait Islanders in the Second World War', Strategic and Defence Studies, Working Paper no 121, Research School of Pacific Studies, Australian National University, 1987

The relationship between Aborigines, Islanders and the Armed Forces in the Second World War', PhD, Australian Defence Force Academy, University of New South Wales, 1988

Rowley C. D., Outcasts in white Australia (Aboriginal policy and practice, vol.2), Canberra, 1971 